УПОРЕДНА АНАЛИЗА КОД УМРЛИХ ОД ИСХЕМИЈСКЕ

КОРОНАРНЕ БОЛЕСТИ СРЦА ПРЕМА ПОЛУ, СТАРОСТИ И ТЕЖИНИ СРЦА

Љиљана Кулић ${ }^{1}$, Гордана Арсић Комљеновић², Марија Јовановић³ ${ }^{3}$ Мирјана Шијан Гобељић ${ }^{4}$, Христо Анђелски

\title{
PARALEL ANALYSIS OF OBDUCTED DEAD FROM ISCHEMIC CORONARY HEART DISEASES BY GENDER, AGE AND HEART WEIGHT
}

Ljiljana Kulić, Gordana Arsić Komljenović, Marija Jovanović, Mirjana Šijan Gobeljić, Hristo Anđelski

\section{Сажетак}

Коронарна болест сриа једна је од најчешћих болести са смртним исходом y високо-индустријализованим земљама. Вршена је анализа просечне старости обдукованих испитаника, нихова полна структура и анализа у односу на тежину срияа обдукованих испитаника са исхемијском болешћу срия.

Анализа је показала следеће:

- Старост испитаника: Просечна старост испитаника је 67,4 $\pm 11,5$ и то мушка-

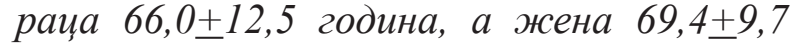
година и нема статистички значајних разлика у просечној старости између жена и мушкарача умрлих од исхемијске болести срия. Број умрлих од исхемијске болести сриа је највећи у старости 50-80 година (80,1\%), а посебно у добној групи 70-79 година $(32,4 \%)$.

- Анализом резултата обдукованих у односу на полну структуру, од укупно 152 испитаника било је 97 (63,8\%) особа мушког пола и 55 (36,2\%) особа женског пола, при чему је заступљеност испитаника мушког пола већа од женског.

\section{Summary}

Coronary heart disease is one of the most common death-cause diseases in highindustrial countries. An analysis of obducted patients' average age, their gender structure and heart weight analysis of patients with ischemic coronary disease has been performed.

The analysis has shown the following:

- Age of the examinees: Average age of the examinees is $67,4 \pm 11,5$, and it's at men $66,0 \pm 12,5$ years, and women $69,4 \pm 9,7$ years, and there are no statistically significant differences in average age among men and women died from ischemic heart disease. The number of dead from ischemic heart disease is highest in the age between 50-80 years $(80,1 \%)$, and specially in the age group of 70 79 years $(32,4 \%)$.

- Analysis of results of obducted, comparing age structure, showed that from altogether 152 examinees there were 97 males $(63,8 \%)$ and 55 females $(36,2 \%)$, so the conclusion is that there are more males than females.

\footnotetext{
' Др мед. Љиљана Кулић, Висока медицинска школа струковних студија „Милутин Миланковић“, Београд.

2 Др мед. Гордана Арсић Комљеновић, Висока медицинска школа струковних студија „Милутин Миланковић“, Београд.

3 Др Марија Јовановић, Висока медицинска школа струковних студија „Милутин Миланковић“, Београд.

${ }^{4}$ Др Мирјана Шијан Гобељић, Висока медицинска школа струковних студија „Милутин Миланковић“, Београд.

5 Др мед. Христо Анђелски, Висока медицинска школа струковних студија „Милутин Миланковић“, Београд.
} 
- Тежниа срца испитаника је 220-930гр, и то: мушкараиа 220-930гр, а жена 300650гр. Просечна тежина сриа испитаника

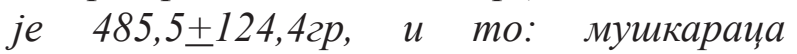
517,3+136гр, ажена 429,6+73,8гр. Постоји статистички високо значајна разлика $(p<0,001)$ у просечној тежсини сриа између обдукованих мушкараца и жена, тако да је тежина сриа значајно већа код мушкараца.

Кључне речи: коронарна болест, срие, пол, старост испитаника, тежина сриа.
- Heart weight of the examinees is 220 930g, and in males' case it's 220-930g, and in females' 300-650g. Average heart weight of the examinees is 485,5+124,4, in males' case

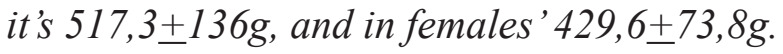
There is a statistically very significant difference $(p<0,001)$ in average heart weight of the obducted men and women, so that the heart weight is considerably bigger with men.

Key words: coronary disease, heart, gender, age, heart weight.

\section{УВОД}

$\mathrm{K}$ оронарна болест срца манифестује се у великом броју различитих клиничких облика, који се крећу од асимптоматских облика преко ангине пекторис на напор, нестабилне ангине пекторис, акутног инфаркта миокарда, спазма коронарних артерија до напрасне смрти. У приближно 99\% случајева коронарна болест је узрокована атеросклеротичним променама, а само $1 \%$ је узрокована другим узроцима (артеритиси, емболија коронарних артерија, обољења везивног ткива, системски лупус еритематодес, изоловани спазам коронарних артерија, сифилис и др). Болести срца и крвних судова су најчешћи узрок смрти људи, нарочито у старосном добу преко 65 година. Од ових болести у свету сваке године умре више од 12 милиона људи. Око 80\% свих облика срчаних болести су болести крвних судова, а само $20 \%$ су обољења самог срца. Коронарна болест срца једна је од најчешћих болести са смртним исходом у високо-индустријализованим земљама. У САД-у она је узрочник једне трећине до једне половине свих смртних случајева и чини 50-75\% свих смртних случајева у болесника са обољењем срца. Значај коронарне болести превазилази висок морбидитет и морталитет овог обољења.
Клиничке манифестације обољења су непредвидиве или одсутне; клинички ток је различит; у једне трећине до једне половине болесника смрт је изненадна и неочекивана. Инфаркт миокарда представља једно од најчешћих ургентних стања у интерној медицини. Инфаркт миокарда има висок морбидитет, инвалидитет и морталитет. Напрасна смрт чини половину случајева, а морталитет услед инфаркта миокарда чини приближно трећину укупног морталитета уопште. Ванболничка смртност чини 75\%, а хоспитална $25 \%$ у структури смртности од акутног инфаркта миокарда. У атипичом облику инфаркт миокарда је присутан у $25-40 \%$, случајева, а у $20 \%$ случајева је асимптоматски.

\section{ЦИЉ РАДА}

Вршена је анализа просечне старости обдукованих испитаника, њихова полна структура и анализа у односу на тежину срца обдукованих испитаника са исхемијском болешћу срца. Наиме, циљ рада је био да се анализира патолошки налаз на срцу умрлих пацијената са исхемијском коронарном болешћу срца (ИКБ) у односу на пол, старост и тежину срца. 


\section{МАТЕРИЈАЛ И МЕТОДЕ}

Истраживачка група састојала се од 152 обдукована случаја и њу су чинили случајеви са знацима атеросклеротичне коронарне болести срца. Примењене су патолошко -морфолошке методе истраживања: обдукција, макроскопска дијагностика и микроскопска анализа. У обради КА одвојене су све КА: десна коронарна артерија (ДКА), стабло леве коронарне артерије (ЛКА), лева циркумфлексна грана (ЛЦ) и лева предња десцедентна грана (ЛПД). КА су сечене попречним резовима у сегменте дужине $5 \mathrm{~mm}$. На попречним хистопатолошким пресецима мерен је проценат сужења лумена, при чему је као сигнификантно значајно сужење означено сужење $>75 \%$. Степен сужења КА на попречном пресеку сврстан је у четири степена: $0-25 \%, 26-50 \%, 51-$ $75 \%$ и $76-100 \%$.

Узети исечци ткива фиксирани су у $4 \%$ пуферованом формалину, калупљени у парафинске блокове и сечени у препарате дебљине 4-6 микрометра. Микроскопски исечци бојени су стандардном методом бојења хематоксилин еозин (XE). Поред рутинске ХЕ методе примењене су следеће хистохемијске методе бојења: Van Gieson elastica, Grimelius и Masson fontana метода.

У овом истраживању вршена је патохистолошка анализа срца 152 обдукована пацијената умрла од исхемијске коронарне болести срца (ИКБ) у временском периоду од десет година. Анализиране су патохистолошке промене на коронарним артеријама и миокарду, локализација првог и поновног инфаркта миокарда, учесталост и локализација руптуре срца, величина инфарктног поља зависно од начина умирања пацијената, састав АТ плака у групама са инфарктом миокарда и код изненадне коронарне смрти, компаративна анализа степена сужења коронарних артерија и састава АТ плака.

У конкретном приказу резултата биће коментарисани и биће вршена анализа просечне старости обдукованих испитаника, њихова полна структура и анализа у односу на тежину срца обдукованих испитаника са исхемијском болешћу срца.

\section{РЕЗУЛТАТИ РАДА}

Вршена је анализа просечне старости обдукованих испитаника са исхемијском болешћу срца, што је приказано на графикону 1.

Графикон 1. Обдуковани испитаниции са исхемијском коронарном болешћу срияа, према старости $(N=111)$.

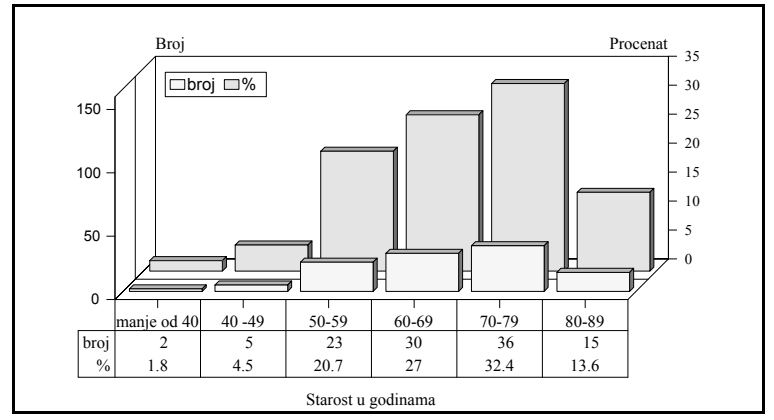

Од укупно 152 обдукована пацијента са ИКБ било је 97 особа мушког пола и 55 особе женског пола. Уколико се анализира полна структура оболелих и умрлих испитаника, уочљиво је да је већа заступљеност особа мушког (97, односно $63.8 \%$ ) у односу на особе женског пола (55, односно $36.2 \%$ ), што је приказано на графикону 2 и табели 1.

Графикон 2. Обдуковани испитаници са исхемијском коронарном болешћу сриа, према полу $(N=152)$.

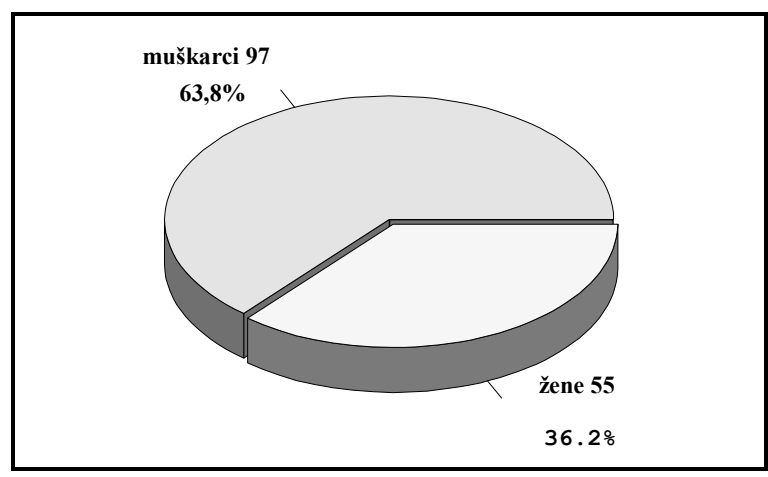


Табела 1. Обдуковани испитаници са патоморфолошким налазом на сриу и коронарним артеријама према старости и полу.

\begin{tabular}{|c|c|c|c|}
\hline \multicolumn{4}{|c|}{$\begin{array}{l}\text { Обдуковани испитаници са патоморфолошким налазом на } \\
\text { срцу и коронарним артеријама }\end{array}$} \\
\hline \multirow[t]{2}{*}{ Статистички параметри } & \multicolumn{2}{|c|}{ Пол } & \multirow[t]{2}{*}{ 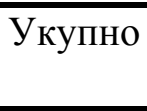 } \\
\hline & мушки & женски & \\
\hline Број испитаника & 67 & 44 & 111 \\
\hline Минимална вредност & 39 & 39 & 39 \\
\hline Максимална вредност & 87 & 89 & 89 \\
\hline Просечна вредност & 66.04 & 69.39 & 67.37 \\
\hline Стандардна девијација & 12.50 & 9.67 & 11.53 \\
\hline Коефицијент варијације у \% & 18.92 & 13.94 & 17.11 \\
\hline \multicolumn{4}{|l|}{$\begin{array}{l}\text { Интервал поузданости за } \\
\text { вероватноћу } \mathrm{p}=0.95\end{array}$} \\
\hline - доња граница & 63.05 & 66.53 & 65.22 \\
\hline - горња граница & 69.04 & 72.24 & 69.52 \\
\hline $\begin{array}{c}\text { Значајност разлика у } \\
\text { просечној старости, t-test }\end{array}$ & \multicolumn{2}{|c|}{$\mathrm{t}=1.506 ; \mathrm{p}>0.05$} & \\
\hline
\end{tabular}

Анализа података о старости је показала:

1. да се старост обдукованих:

- мушкараца креће од 39 до 87 година,

- жена креће од 39 до 89 година,

- укупно креће од 39 до 89 година;

2. да је просечна старост:

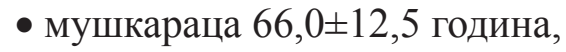

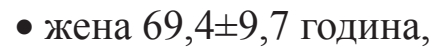

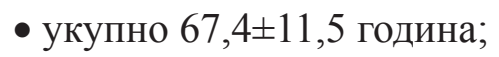

3. да су коефицијенти варијације у свим анализираним групама болесника мањи од $30 \%$, па се може сматрати да су појединачни подаци међусобно хомогени и погодни за статистичка закључивања;
4. да се са вероватноћом $\mathrm{p}=0.95$ може очекивати да се у основном скупу из кога је добијен анализирани узорак просечна старост обдукованих креће:

- код мушкараца од 63 до 69 година,

- код жена од 67 до 72 године,

- укупно од 65 до 69 година;

5. да нема статистички значајних разлика у просечној старости између обдукованих мушкараца и жена.

Патолошком анализом срца обдукованих мерена је између осталог тежина срца. Вршена је анализа резултата патоморфолошког налаза на срцу и коронарним артеријама горе поменутих испитаника према тежини срца и полу (табела 2). 
Табела 2. Обдуковани испитанищи са патоморфолошким налазом на сриу и коронарним артеријама.

\begin{tabular}{|c|c|c|c|}
\hline \multicolumn{4}{|c|}{$\begin{array}{l}\text { Обдуковани испитаници са патоморфолошким налазом на } \\
\text { срцу и коронарним артеријама према тежини срца и полу }\end{array}$} \\
\hline \multirow[t]{2}{*}{ Статистички параметри } & \multicolumn{2}{|c|}{ Пол } & \multirow[t]{2}{*}{ Укупно } \\
\hline & мушки & женски & \\
\hline Број испитаника & 95 & 54 & 149 \\
\hline Минимална вредност & 220 & 300 & 220 \\
\hline Максимална вредност & 930 & 650 & 930 \\
\hline Просечна вредност & 517.26 & 429.63 & 485.50 \\
\hline Стандардна девијација & 135.95 & 73.84 & 124.41 \\
\hline Коефицијент варијације у \% & 26.28 & 17.19 & 25.62 \\
\hline \multicolumn{4}{|l|}{$\begin{array}{l}\text { Интервал поузданости за } \\
\text { вероватноћу } \mathrm{p}=0.95\end{array}$} \\
\hline - доња граница & 489.92 & 409.93 & 465.53 \\
\hline - горња граница & 544.60 & 449.32 & 505.48 \\
\hline $\begin{array}{c}\text { Значајност разлика у } \\
\text { просечној старости, t-те }\end{array}$ & $t=4.380$ & .0003 & \\
\hline
\end{tabular}

На основу података приказаних у табели 2, утврђено је:

1. да се тежина срца обдукованих:

- мушкараца креће од 220гр до 930гр,

- жена креће од 300гр до 650гр,

- укупно креће од 220гр до 930гр;

2. да је просечна тежина срца код:

- мушкараца 517,3гр $\pm 136,0 г р$,

- жена 429,6гр $\pm 73,8 г р$,

- укупно 485,5гр $\pm 124,4 г p ;$

3. да су коефицијенти варијације у свим анализираним групама болесника мањи од $30 \%$, па се може сматрати да су појединачни подаци међусобно хомогени и погодни за статистичка закључивања.

4. да се са вероватноћом $\mathrm{p}=0.95$ може очекивати да се у основном скупу из кога је добијен анализирани узорак просечна тежина обдукованих креће:

- код мушкараца од 490гр до 545гр,

- код жена од 410гр до 449гр,

- укупно од 465,5гр до 505,5гр.

5. да постоји статистички високо значајна разлика $(\mathrm{p}<0.001)$ у просечној тежини срца између обдукованих мушкараца и жена. Наиме, трећина срца је значајно већа код мушкараца.

\section{ДИСКУСИЈА}

Болести срца и крвних судова представљају најчешћи узрок смрти, што показују подаци добијени у истраживањима наших и страних аутора. Коронарна болест срца је узрок смрти кодболесника са обољењемсрца чак у 50-75\% случајева. Ангина пекторис која обично претходи другим облицима болести по подацима Светске здравствене организације има морталитет од 0,3 до $3,8 \%$. Свака четврта особа животног доба 30-40 година у индустријским земљама има истовремено два или више фактора ризика, што за више од 15 пута повећава ризик да оболе од исхемијске болести срца у односу на особе које немају наведене факторе ризика. Код особа које имају више од два фактора ризика у времену 10-20 година настаје акутни инфаркт миокарда или саriac arest, а са степеном, односно, нивоом и дужином експонираности дејству фактора ризика расту заступљеност, компликације и неповољна прогноза исхемијске болести 
срца. Евидентне су унутрашње везе између појединих фактора ризика, односно потенцирање њиховог међусобног штетног дејства.

Од укупно 152 испитаника било је 97 особа мушког пола $(63,8 \%)$ и $55(36,2 \%)$ особа женског пола. Очигледно је да је заступљеност испитаника мушког пола већа од женског.

У испитивању обдукованих са патоморфолошким налазом на срцу и крвним судовима показало се да се старост обдукованих мушкараца креће од 39 до 87 година, жена 39-89 година, а укупно, без обзира на пол, 39-89 година. При томе је просечна старост мушкараца 66,0土12,5 година, жена $69,4 \pm 9,7$ година, аукупно, за ове испитанике, $67,4 \pm 11,5$ година. Просечна старост креће се код мушкараца 63-69 година, код жена 6772 године и код свих укупно 65-69 година. Статистичком обрадом установљено је да нема статистички значајних разлика у просечној старости између обдукованих мушкараца и жена. Истраживања разних аутора су потврдила да постоји тенденција подмлађивања, то јест, померања појаве инфаркта, као и смртног исхода од инфаркта миокарда ка млађим добним групама. У просеку оболевамо од акутног инфаркта миокарда 12-15 година раније од наших предака.

Ово истраживање показује да је највећи број умрлих са исхемијском болешћу срца у добној групи 70-79 година, и то 32,4\%, док је нешто мањи у групи чија је старост 60-69 година (27\%), односно групи чија је старост $50-59$ година $(20,7 \%)$. Број умрлих старости 50-80 година је 89 , односно $80,1 \%$.

Мерена је тежина срца умрлих мушкараца и жена, па је установљено да је тежина срца обдукованих мушкараца 220-930гр, жена 300-650гр, а укупно се креће 220-930 грама. Просечна тежина срца код мушкараца

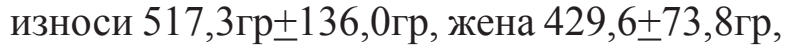
а за све укупно без обзира на пол је $485,5 \pm 124,4$ грама. Пошто су коефицијенти варијације у свим анализираним групама болесника мањи од $30 \%$, сматра се да су појединачни подаци међусобно хомогени и погодни за статистичка закључивања. Просечна тежина срца обдукованих испитаника креће се код мушкараца 490-545гр, а код жена 410-449гр. Просечна тежина срца обдукованих испитаника без обзира на пол креће се 465,5-505,5гр. Постоји статистички високо значајна разлика $(p<0,001)$ у просечној тежини срца између обдукованих мушкараца и жена, тако да је тежина срца значајно већа код мушкараца.

\section{ЗАКЉУЧАК}

Анализа просечне старости обдукованих испитаника, њихова полна структура и анализа у односу на тежину срца обдукованих испитаника са исхемијском болешћу срца показала је следеће:

- Старост испитаника је 39-89 година, и то: старост мушкараца је 39-87 година, а жена 39-89 година. Просечна старост испитаника је $67,4 \pm 11,5$, и то мушкараца $66,0 \pm 12,5$ година, а жена $69,4 \pm 9,7$ година и нема статистички значајних разлика у просечној старости између жена и мушкараца умрлих од исхемијске болести срца. Број умрлих од исхемијске болести срца је највећи у старости $50-80$ година $(80,1 \%)$, а посебно у добној групи 70-79 година $(32,4 \%)$.

- Анализом резултата обдукованих у односу на полну структуру, од укупно 152 испитаника било је 97 (63,8\%) особа мушког пола и 55 (36,2\%) особа женског пола, при чему је заступљеност испитаника мушког пола већа од женског.

- Тежина срца испитаника је 220 930гр, и то: мушкараца 220-930гр, а жена 300-650гр. Просечна тежина срца испитаника је 485,5+124,4гр, и то: мушкараца $517,3 \pm 136 г$, а жена 429,6+73,8гр. Постоји статистички високо значајна разлика $(\mathrm{p}<0,001)$ у просечној тежини срца између обдукованих мушкараца и жена, тако да је тежина срца значајно већа код мушкараца. 


\section{ЛИТЕРАТУРА}

1. Азањац C, Кнежевић M, Кањух В, Кнежевић J, Држајић В, Анђелковић 3, Станковић В, Велимировић Д, Јанчић С, Инфаркт миокарда (патолошко -морфолошке карактеристике у 111 обдукованих болесника. Зборник радова VI Конгреса патолога Југославије, Златибор, 1994; 53-54.

2. Roberts WC, Potkin NB, Solus ED, Shanthasundari GR. Mode of death, frequency of heald and acute myocardial infarction, number of major epicardial coronary arteries severly narrowed by atherosclerotic plaque, and heart weight in fatal atherosclerotic coronary artery disease: Analysis of 889 patients studied at necropsy. J. Am. Coll Cardiol. 1990; 15: 196-203.
3. Roberts WC, Jones AA. Quantitation of coronary arterial narrowing at necropsy in sudden coronary death. Analysis of 31 patients and comparison with 25 control subjects. Am J Cardiol, 1979; 44: 39-45.

4. Ross ME, Roberts WC. Severe Atherosclerotic Coronary Artery Disease, Healed Myocardial Infarction and Chronic Congestive Heart Failure: Analysis of 81 patients Studied at Necropsy, issler $R W A$ definition of advanced types of atherosclerotic lesions and a histological classification of atherosclerosis Arteriosler Thromb. Vasc Biol. 1995; 15: 1512-31.

5. Zaman AG, Helft G, Worthlez SG, Badimon JJ. The role of plaque rupture and thrombosis in coronary artery disease. Atherosclerosis 2000; 149: 251-66.

Контакт: Др мед. Љиљана Кулић, Висока медицинска школа струковних студија „Милутин Миланковић“, Црнотравска 27, Београд 